\title{
By the Light of Day: Quality, Safety, and Education During the Overnight Admission Handoff
}

Ganesh P. Devendra ${ }^{1}$, Gabriel M. Ortiz ${ }^{2}$, Lawrence A. Haber ${ }^{3}$

1. Hospital Medicine, Oregon Health and Sciences University, Portland, USA 2. Internal Medicine, University of California San Francisco, San Francisco, USA 3. Internal Medicine - Hospital Based Medicine, University of California San Francisco, San Francisco, USA

$\square$ Corresponding author: Ganesh P. Devendra, gpdevendra@gmail.com Disclosures can be found in Additional Information at the end of the article

\section{Abstract}

\section{Background}

Current duty hour restrictions have led to increased patient handoffs as well as increased use of faculty in the nocturnist role. Nocturnists typically supervise residents and perform direct patient care leading to a diversity of provider experience level during morning handoffs. In this study, we explored how the presence of nocturnists impacts perceptions patient safety, quality, and educational value of morning care transitions.

\section{Methods}

We performed a cross-sectional survey examining the housestaff and attending perceptions of the morning sign-out of overnight admissions from both night float residents and nocturnists in July of 2016. Survey responses were Likert-style format, querying respondents' level of agreement (1-5, strongly disagree to strongly agree) with statements. 108 providers responded (41\% response rate)

\section{Results}

Relative to attendings, residents reported feeling like they had less time to ask questions (4.0 vs. 5.0, $p<0.001)$ and felt less comfortable asking questions of the nocturnist during handoff (4.0 vs. $5.0, p<0.001$ ). Residents were also less comfortable than attendings in changing a nocturnist's plan of care (4.0 vs. 5.0, $p<0.001)$. Housestaff reported that receiving signout from the overnight resident was more likely to improve their confidence managing similar conditions (4.0 vs. $3.0, p<0.001)$.

Received 03/07/2019

Review began 03/11/2019

Review ended 04/16/2019

Published 04/23/2019

(C) Copyright 2019

Devendra et al. This is an open access article distributed under the terms of the Creative Commons Attribution License CC-BY 3.0., which permits unrestricted use, distribution, and reproduction in any medium, provided the original author and source are credited.

\section{Conclusion}

The benefits of nocturnist supervision may come at an educational cost as trainees feel less comfortable asking questions or changing the plan of care. With increasingly prevalent night float systems and nocturnist providers, academic programs have to negotiate the balancing safe and high-quality patient care with creating positive learning environments and clear expectations.

Categories: Internal Medicine, Medical Education, Quality Improvement

Keywords: hospital medicine, nocturnists, resident education 


\section{Introduction}

Verbal provider-to-provider handoffs are the most common mechanism for transitioning care in the inpatient setting [1]. Handoffs are used to report overnight events on previously admitted patients, and introduce providers to new admissions. The 2011 duty hour restrictions reduced inpatient resident shift length, leading to increased transitions of care between providers [2-3]. Increasingly frequent patient handoffs may jeopardize patient safety, as the process is variable, unstructured, and error prone [1,4-10]. Subsequently, there has been growing housestaff education focusing on improving and standardizing inpatient provider transitions [11-12].

Increased housestaff supervision mandates and duty hour restrictions have led academic training institutions to employ overnight in-hospital faculty (nocturnists) [13-15]. Nocturnists can provide direct overnight supervision of trainees as well as perform direct patient care duties to offload resident workload. Prior investigation has shown that residents found nocturnist presence enhanced the clinical value of the night float rotation, without compromising housestaff decision-making autonomy [16-18]. No prior studies have examined the morning transition of care of newly hospitalized patients in this current academic environment, where patient care by overnight resident and faculty physicians is transferred to daytime clinicians.

We examined perspectives of faculty and trainee daytime providers receiving new admissions from overnight hospitalists and residents with respect to the quality of information transmission, handoff safety, and educational experience of receiving physicians. Our goal was to identify barriers to safe, high-quality care of the newly hospitalized patient at academic institutions and inform best practices for standardizing this increasingly frequent transition of care.

\section{Materials And Methods}

Our study was conducted at a 183-bed urban safety-net medical center affiliated with an internal medicine residency program of 170 housestaff. During the resident "night float" rotation at our hospital, second- and third-year residents complete seven days of overnight shifts. Shift duration is 13 hours, beginning at $8 \mathrm{pm}$ and ending at $9 \mathrm{am}$, and involves admitting general medicine patients to the floor and step-down units, as well as supervising the crosscovering medicine intern. Since 2011, direct overnight supervision of the nighttime housestaff has been provided by an on-site attending physician. This nocturnist also admits patients in a 1:1 ratio with the resident, manages transfer requests from outside hospitals, performs medicine consults, and organizes patient distribution to the day teams based on team census levels. The majority of these shifts are staffed by dedicated nocturnists, all junior faculty within the Division of Hospital Medicine, with approximately one-fifth of shifts staffed by moonlighting physicians who have completed residency training. Overnight admissions by both housestaff and nocturnist are then handed off to the day teams via a full presentation to residents, interns, and attending of the accepting team. Attending physicians from divisions of hospital medicine, general internal medicine, and subspecialists all staff our general medicine services. Time allotted to overnight presentations is one hour between 8 and 9 am with presentations typically taking place in a conference room, not at the bedside.

We administered a cross-sectional survey in July 2016 to all current internal medicine housestaff who cared for patients during day time on the inpatient general medicine service at our institution in the past four academic years (since the advent of our current the overnight system). We administered the same survey to internal medicine faculty who had attended on the general medicine teaching services in the past four years. Residents and faculty who had not worked at the hospital or who had not received overnight handoffs during the allotted time were excluded from the survey. 
Surveys examined housestaff and attending perceptions of the morning sign-out of overnight admissions from both night float residents and nocturnists. Questions pertained to the quality and safety of information transmission and the educational experience of receiving providers. Surveys were designed based on prior literature, personal experience, and expert suggestion and refined in works in progress meetings (16-18). Survey responses were Likert-style format, querying respondents' level of agreement (1-5, strongly disagree to strongly agree) with statements. Surveys were disseminated via e-mail by one of the study investigators (GD), with embedded informed consent and a link that connected anonymously to the online survey (Qualtrics, Provo, UT). We did not collect unique identifiers and offered no incentive for participation. Data were downloaded to a secure database and analyzed using JMP 14 software (SAS Institute, Inc., Cary, North Carolina). Data are presented as median \pm interquartile range. Comparisons between medians were done by the Wilcoxon test. For all data, a $P$-value of $\leqslant 0.05$ was considered statistically significant. The study was approved by the institutional review board.

\section{Results}

A total of 108 providers responded (41\% response rate) to the survey with five participants excluded for not having received overnight handoffs. Of the remaining 103 participants, there were 29 faculty and 74 residents. Attending physicians had an average age of $45( \pm 12.7)$ years, with a median experience of five years. Of faculty respondents, 13 were hospitalists, three were general internists, 10 were subspecialists, and three declined to respond. Resident physicians had an average age of 29.8 ( \pm 2 ) years and included 29 post-graduate year 1 (PGY1), 27 PGY2, 18 PGY3, and 2 PGY4.

\section{Quality and safety of the handoff}

When comparing housestaff and attendings responses, residents preferred receiving signout from the overnight resident, while attendings preferred signout from the nocturnist (Table 1). Attendings better understood "to dos" (specific uncompleted tasks) when receiving signout from nocturnists and reported that nocturnists better communicated pending tests and were more likely to complete medication reconciliation. Housestaff felt that the overnight residents were more likely to model professional behavior during the handoff, while attendings reported no difference in professional behavior between the groups. 


\section{Cureus}

\begin{tabular}{|c|c|c|c|c|c|c|c|c|}
\hline $\begin{array}{l}\text { A) } \\
\text { Resident } \\
\text { Handoff }\end{array}$ & $\begin{array}{l}\text { Records } \\
\text { Summarized }\end{array}$ & $\begin{array}{l}\text { Overnight Events } \\
\text { Communicated }\end{array}$ & $\begin{array}{l}\text { "To Dos" } \\
\text { Understood }\end{array}$ & $\begin{array}{l}\text { Professional } \\
\text { Behavior } \\
\text { Modeled }\end{array}$ & $\begin{array}{l}\text { Handoff } \\
\text { Efficient }\end{array}$ & $\begin{array}{l}\text { Prefer Handoff } \\
\text { from Resident }\end{array}$ & $\begin{array}{l}\text { Med Rec } \\
\text { Complete }\end{array}$ & $\begin{array}{l}\text { Pending Tests were } \\
\text { Communicated }\end{array}$ \\
\hline Residents & $3.0(3.0-4.0)$ & $4.0(4.0-4.0)$ & $4.0(4.0-4.0)$ & $5.0(4.0-5.0)$ & $\begin{array}{l}3.0(3.0- \\
4.0)\end{array}$ & $4.0(3.0-4.0)$ & $\begin{array}{l}3.0(3.0- \\
4.0)\end{array}$ & $4.0(3.0-4.0)$ \\
\hline Attendings & $4.0(3.0-4.0)$ & $4.0(3.0-4.0)$ & $4.0(3.0-4.0)$ & $4.0(4.0-5.0)$ & $\begin{array}{l}3.0(3.0- \\
4.0)\end{array}$ & $3.0(1.75-4.0)$ & $\begin{array}{l}3.5(2.75- \\
4.0)\end{array}$ & $4.0(4.0-4.0)$ \\
\hline$p$-value & 0.97 & 0.49 & 0.2 & 0.03 & 0.78 & $<0.001$ & 0.21 & 0.4 \\
\hline $\begin{array}{l}\text { B) } \\
\text { Nocturnist } \\
\text { Handoff }\end{array}$ & $\begin{array}{l}\text { Records } \\
\text { Summarized }\end{array}$ & $\begin{array}{l}\text { Overnight Events } \\
\text { Communicated }\end{array}$ & $\begin{array}{l}\text { "To Dos" } \\
\text { Understood }\end{array}$ & $\begin{array}{l}\text { Professional } \\
\text { behavior modeled }\end{array}$ & Efficient & Prefer Nocturnist & $\begin{array}{l}\text { Med Rec } \\
\text { Complete }\end{array}$ & $\begin{array}{l}\text { Pending Tests were } \\
\text { Communicated }\end{array}$ \\
\hline Residents & $4.0(3.0-4.0)$ & $4.0(4.0-4.0)$ & $4.0(4.0-4.0)$ & $4.0(4.0-5.0)$ & $\begin{array}{l}4.0(4.0- \\
4.0)\end{array}$ & $2.0(2.0-3.0)$ & $\begin{array}{l}3.0(3.0- \\
4.0)\end{array}$ & $4.0(3.0-4.0)$ \\
\hline Attendings & $4.0(3.0-4.0)$ & $4.0(4.0-5.0)$ & $4.0(4.0-5.0)$ & $4.0(4.0-5.0)$ & $\begin{array}{l}4.0(4.0- \\
5.0)\end{array}$ & $4.0(3.0-5.0)$ & $\begin{array}{l}4.0(3.0- \\
4.0)\end{array}$ & $4.0(4.0-4.0)$ \\
\hline$p$-value & 0.07 & 0.07 & 0.003 & 0.85 & 0.18 & $<0.001$ & 0.009 & $<0.001$ \\
\hline
\end{tabular}

TABLE 1: A comparison between resident and attending perceptions of (A) resident and (B) nocturnist handoffs with respect to quality \& safety of transmission of information, responses scaled from 1-5, (strongly disagree to strongly agree), median (interquartile range)

\section{Educational value of the handoff}

Relative to receiving attendings, residents reported less time to ask questions and less comfort asking questions of the nocturnist during handoff (Table 2). Residents were less comfortable than attendings changing a nocturnist's plan of care. Housestaff reported that receiving signout from the overnight resident was more likely to improve their confidence managing similar conditions. Attendings were more likely to feel ownership of the patient than residents were, irrespective of whether handoff came from a nocturnist or overnight resident. 


\section{Cureus}

\begin{tabular}{|c|c|c|c|c|c|c|}
\hline $\begin{array}{l}\text { A) } \\
\text { Resident } \\
\text { Handoff }\end{array}$ & $\begin{array}{l}\text { I am } \\
\text { Comfortable } \\
\text { Asking } \\
\text { Questions }\end{array}$ & $\begin{array}{l}\text { I Have } \\
\text { Time to } \\
\text { Ask } \\
\text { Questions }\end{array}$ & $\begin{array}{l}\text { Handoff Improved my } \\
\text { Confidence Managing } \\
\text { Similar Conditions }\end{array}$ & $\begin{array}{l}\text { I Feel } \\
\text { Ownership } \\
\text { of the } \\
\text { Patient }\end{array}$ & $\begin{array}{l}\text { I am } \\
\text { Comfortable } \\
\text { Changing the } \\
\text { Plan }\end{array}$ & $\begin{array}{l}\text { Care } \\
\text { Demonstrated } \\
\text { Evidence-based } \\
\text { Medicine }\end{array}$ \\
\hline Residents & $5.0(4.0-5.0)$ & $\begin{array}{l}4.0(4.0- \\
5.0)\end{array}$ & $4.0(3.0-4.0)$ & $\begin{array}{l}4.0(4.0- \\
5.0)\end{array}$ & $5.0(4.0-5.0)$ & $4(4-4)$ \\
\hline Attendings & $5.0(4.75-5.0)$ & $\begin{array}{l}5.0(3.0- \\
5.0)\end{array}$ & $3.0(2.0-3.0)$ & $\begin{array}{l}5.0(3.75- \\
5.0)\end{array}$ & $5.0(4.0-5.0)$ & $4(4-4)$ \\
\hline p-value & 0.55 & 0.37 & $<0.001$ & 0.03 & 0.64 & 0.75 \\
\hline $\begin{array}{l}\text { B) } \\
\text { Nocturnist } \\
\text { Handoff }\end{array}$ & $\begin{array}{l}\text { Comfortable } \\
\text { asking } \\
\text { questions }\end{array}$ & $\begin{array}{l}\text { Time to ask } \\
\text { questions }\end{array}$ & Improved my confidence & $\begin{array}{l}\text { Ownership } \\
\text { of the case }\end{array}$ & $\begin{array}{l}\text { Comfortable } \\
\text { changing the } \\
\text { plan }\end{array}$ & Evidence-based \\
\hline Residents & $4.0(3.0-4.75)$ & $\begin{array}{l}4.0(3.0- \\
4.0)\end{array}$ & $3.0(3.0-4.0)$ & $\begin{array}{l}4.0(3.0- \\
5.0)\end{array}$ & $4.0(3.0-5.0)$ & $4(4-4)$ \\
\hline Attendings & $5.0(4.0-5.0)$ & $\begin{array}{l}5.0(4.0- \\
5.0)\end{array}$ & $3.0(3.0-4.0)$ & $\begin{array}{l}5.0(4.25- \\
5.0)\end{array}$ & $5.0(4.0-5.0)$ & $4(4-5)$ \\
\hline$p$-value & $<0.001$ & $<0.001$ & 0.55 & $<0.001$ & 0.009 & 0.49 \\
\hline
\end{tabular}

TABLE 2: Resident and attending perceptions of (A) resident and (B) nocturnist handoffs with respect to educational value of the handoff, responses scaled from 1-5, (strongly disagree to strongly agree), median (interquartile range)

\section{Discussion}

Despite positive faculty views of the nocturnist handoff and the potential benefits to trainees of faculty role-modeling, residents still preferred receiving signout from their overnight colleagues. Integration of practicing overnight faculty into the training environment may come at an educational cost, as housestaff felt they had less time to ask questions of the nocturnist, were less likely to change care plans, and that nocturnist signout was less likely to improve their confidence managing similar cases. The use of overnight attending physicians to perform direct patient care activities may contribute to scenarios where trainees feel unable to question management plans during the patient handoff, impairing reassessment and predisposing to anchor bias. Training programs should consider building systems that, when feasible, give preference to overnight residents presenting new admissions to teaching teams, as housestaff reported such handoffs improved their confidence managing similar conditions, provided adequate time for questions, and encouraged patient ownership.

In 2013, Dhaliwal and Hauer wrote on the need to update the format and content of the overnight admission presentation in the era of prevalent nigh float systems [19]. As we adapt the traditional oral patient presentation to current practice, our study emphasizes the importance of considering nocturnists in this restructuring. Given the demonstrated reluctance of trainees to ask questions of attendings or change care plans, when nocturnists do present new patients to teams of trainees, a deliberate structure should mandate dedicated time for 
housestaff questions and proactive trainee reevaluation of the working diagnosis.

In addition, our study highlights potential differences between overnight attending and resident presentations with regard to the quality of information transmission. To eliminate handoff disparities, programs should consider constructing scripts for morning presentations that include overnight "always events" (items such as medication reconciliation status, pending tests, and incomplete tasks). Standardization of both the form and content of morning handoffs may help mitigate handoff errors.

There are several limitations to our study. First, the findings represent the experience of internal medicine residents and attendings at a single academic, safety-net hospital and may not be generalizable to other institutions or specialties. Second, we asked respondents to recall patient handoffs from the prior year, which may have introduced recall bias. Third, responses of junior and senior housestaff were pooled, which may weight responses in favor of higher responding groups (more junior trainees, in our study). Finally, we reported only resident and attending perceptions of the quality, safety, and educational value of the overnight admission handoff, and not direct measures of knowledge or patient care outcomes. Further research should explore patient-level clinical outcomes for patients admitted by overnight residents and nocturnists as well as direct measures of difference in knowledge acquisition from overnight resident and attending handoffs.

\section{Conclusions}

With increasingly prevalent night float systems and nocturnist providers, academic programs have to negotiate balancing safe and high-quality patient care with creating positive learning environments and clear expectations. A modern approach to handoffs of overnight admissions involves standardizing core content for presentations and ensuring a structure containing dedicated time for trainees' questions and diagnostic reassessment.

\section{Additional Information \\ Disclosures}

Human subjects: Consent was obtained by all participants in this study. The Human Research Protection Program at University of California San Francisco issued approval NA. Animal subjects: All authors have confirmed that this study did not involve animal subjects or tissue. Conflicts of interest: In compliance with the ICMJE uniform disclosure form, all authors declare the following: Payment/services info: All authors have declared that no financial support was received from any organization for the submitted work. Financial relationships: All authors have declared that they have no financial relationships at present or within the previous three years with any organizations that might have an interest in the submitted work. Other relationships: All authors have declared that there are no other relationships or activities that could appear to have influenced the submitted work.

\section{References}

1. Manser T, Foster S: Effective handover communication: an overview of research and improvement efforts. Best Pract Res Clin Anaesthesiol. 2011, 25:181-191. 10.1016/j.bpa.2011.02.006

2. Nasca TJ, Day SH, Amis ES, Jr: The new recommendations on duty hours from the ACGME task force. N Engl J Med. 2010, 363:3. 10.1056/NEJMsb1005800

3. Devlin MK, Kozij NK, Kiss A, Richardson L, Wong BM: Morning handover of on-call issues: opportunities for improvement. JAMA Intern Med. 2014, 174:1479-1485.

10.1001/jamainternmed.2014.3033

4. Fletcher KE, Davis SQ, Underwood W, Mangrulkar RS, McMahon LF, Jr, Saint S: Systematic 
review: effects of resident work hours on patient safety. Ann Intern Med. 2004, 141:851-857.

5. Horwitz LI, Moin T, Krumholz HM, Wang L, Bradley EH: Consequences of inadequate sign-out for patient care. Arch Intern Med. 2008, 168:1755-1760. 10.1001/archinte.168.16.1755

6. Singh H, Thomas EJ, Petersen LA, Studdert DM: Medical errors involving trainees: a study of closed malpractice claims from 5 insurers. Arch Intern Med. 2007, 167:2030-2036.

10.1001/archinte.167.19.2030

7. Kitch BT, Cooper JB, Zapol WM, Marder JE, Karson A, Hutter M, Campbell EG: Handoffs causing patient harm: a survey of medical and surgical house staff. Jt Comm J Qual Patient Saf. 2008, 34:563-570.

8. Rattray NA, Flanagan ME, Militello LG, et al.: "Do you know what I know?": how communication norms and recipient design shape the content and effectiveness of patient handoffs. J Gen Intern Med. 2019, 34:264-271. 10.1007/s11606-018-4755-5

9. Militello LG, Rattray NA, Flanagan ME, et al.: "Workin' on our night moves": how residents prepare for shift handoffs. Jt Comm J Qual Patient Saf. 2018, 44:485-493. 10.1016/j.jcjq.2018.02.005

10. Mardis M, Davis J, Benningfield B, et al.: Shift-to-shift handoff effects on patient safety and outcomes. Am J Med Qual. 2017, 32:34-42. 10.1177/1062860615612923

11. Nasca TJ, Philibert I, Brigham T, Flynn TC: The next GME accreditation system--rationale and benefits. N Engl J Med. 2012, 366:1051-1056. 10.1056/NEJMsr1200117

12. Catalano K: JCAHO'S National Patient Safety Goals 2006. J Perianesth Nurs. 2006, 21:6-11. 10.1016/j.jopan.2005.11.005

13. Patel MS, Volpp KG, Small DS, et al.: Association of the 2011 ACGME resident duty hour reforms with mortality and readmissions among hospitalized Medicare patients. JAMA. 2014, 312:2364-2373. 10.1001/jama.2014.15273

14. Oshimura JM, Sperring J, Bauer BD, Carroll AE, Rauch DA: Changes in inpatient staffing following implementation of new residency work hours. J Hosp Med. 2014, 9:640-645. 10.1002/jhm.2242

15. Farnan JM, Burger A, Boonyasai RT, et al.: Survey of overnight academic hospitalist supervision of trainees. J Hosp Med. 2012, 7:521-523. 10.1002/jhm.1961

16. Haber LA, Lau CY, Sharpe BA, Arora VM, Farnan JM, Ranji SR: Effects of increased overnight supervision on resident education, decision-making, and autonomy. J Hosp Med. 2012, 7:606610. 10.1002/jhm.1959

17. Phy MP, Offord KP, Manning DM, Bundrick JB, Huddleston JM: Increased faculty presence on inpatient teaching services. Mayo Clin Proc. 2004, 79:332-336. 10.4065/79.3.332

18. Trowbridge RL, Almeder L, Jacquet M, Fairfield KM: The effect of overnight in-house attending coverage on perceptions of care and education on a general medical service. J Grad Med Educ. 2010, 2:53-56. 10.4300/JGME-D-09-00056.1

19. Dhaliwal G, Hauer KE: The oral patient presentation in the era of night float admissions: credit and critique. JAMA. 2013, 310:2247-2248. 10.1001/jama.2013.282322 